\title{
Catholicism in Day-to-Day Life in Argentina During a Pandemic Year: Blurring the Institutional Boundaries
}

\author{
Verónica Giménez Béliveau ${ }^{1}$
}

Received: 30 January 2021 / Accepted: 15 April 2021 / Published online: 4 May 2021

(C) The Author(s), under exclusive licence to Springer Nature Switzerland AG 2021

\begin{abstract}
The 2020 COVID-19 pandemic and the policies implemented by states in response to it have created a new global scene. Religious practices, as the majority of social exchanges, are carried out at home. This new context raises again one of the most interesting questions in the analysis of contemporary religiosity in Latin America: the relations between the faithful and the institution, the individual, and the society. This article analyzes the everyday life religious practices of Catholic individuals during pandemic and lockdown times in Argentina, based on field work conducted from March to December 2020 using digital ethnography tools. The article focuses on how religions face the pandemic situation and people's demands, the renewed importance gained by the home's intimate spaces which were newly sacralized as they became the center of everyday religious practices, and the rituals which emerge from online communication. The conclusions emphasize the importance accorded by communities to emotional support and the management of emotions and to coping with personal and family problems. Besides, the article states that Catholic communities develop theologically and ideologically contrasting projects through a differentiated use of online media.
\end{abstract}

Keywords Catholicism $\cdot$ Religious practices $\cdot$ Pandemic times $\cdot$ Virtual religiosity $\cdot$ Day-today life $\cdot$ Argentina

In contemporary society, people's everyday life develops in networks of economic, affective, sexual, and labor exchanges. Religious and spiritual bonds are part of this fabric, which involves multidirectional relationships with both male and female religious leaders, other believers, non-human entities, as well as with texts, objects, and

Verónica Giménez Béliveau

vgimenez@ceil-conicet.gov.ar; veronicagimenezb@gmail.com

1 Ceil-CONICET (Center for Labour Studies, National Scientific and Technical Research Council), University of Buenos Aires, Saavedra 15, (1083) Buenos Aires, Argentina 
places considered as sacred. This landscape includes institutions, which uphold projects of collective perpetuation and are affected by the processes which subjects go through in constructing their identity. Western modernity has strained the relation between subjects and institutions, something which has given rise to numerous theories and interpretations which lie at the base of social sciences. This conceptual pair continues to generate debate: indeed, the relation between the faithful and institutions is perhaps one of the most interesting questions in the analysis of contemporary religiosity in Latin America.

The 2020 COVID-19 pandemic and the policies implemented by states in response to it put an unprecedented stress on social relationships: although it is not the first time that humanity has faced an epidemic, the interconnections which facilitate access to the world aided its rapid spread, the communication of health measures in different countries, and the dissemination of local social practices across the global scene. Lockdown policies were imposed to prevent the circulation of the virus: staying at home became an imperative and a day-to-day reality for people everywhere in the world. The home became the setting of economic, affective, sexual, and labor exchanges, as well as of spiritual and religious ones, concentrating everyday interactions in a confined space.

The purpose of this article is to analyze religiously marked day-to-day interactions during pandemic times, focusing specifically on Catholicism in Argentina. The formulation of this goal requires some methodological and theoretical clarifications. With regard to the epistemological and methodological perspective, the starting point of this research is a number of virtual interactions studied between March and December 2020. The lockdown in Argentina was strictly observed at the beginning, and the celebration of religious services, like other social activities, was not allowed for months. Restrictions on movement also affected social researchers, who were forced to rethink their field work strategies with the help of digital ethnography tools (Hine 2015; Bárcenas Barajas 2019). During 2020 (between March and December), I observed the virtual interactions of Catholic groups with which I had already been working and of others that I began to study. I started to follow the publications released by the Episcopal Conference of Argentina at important moments of the Catholic calendar: the Easter celebration and the Youth Pilgrimage Walk to Luján. The groups that I followed (a Charismatic ministry, a parish in the periphery of the city of Buenos Aires, and a political-religious group) held virtual celebrations and meetings, organized spiritual retreats, and arranged the distribution of social aid. I attended all of these activities. In addition, I conducted telephone interviews and teleconferences, observed interactions through platforms, and had informal conversations with participants. My attention was drawn by new virtual interactions: a number of young religious men and women from different Latin American countries created a group on different social media (Instagram, TikTok, Facebook) through which they show consecrated life from innovative perspectives. For those of us who apply qualitative methodologies, research conditions were definitely very different from the ones we are used to, but this new scenario allowed us to conduct our research in a new setting, i.e., the interface between online and offline religion (Campbell and Vitullo 2016), and to observe everyday practices that were less accessible in the past. The fact that I already knew the groups, their leaders and members undoubtedly facilitated access to the field and enabled me to reflect on interactions in different formats and on the transformations that they experience in the transition from in-person to virtual communication. As a result of the modalities imposed on us, I also 
oriented my observations according to other questions, which were more centered on people and their interactions rather than on institutional structures.

This leads to the second clarification, which is related to the vantage point for looking at institutions. From secularization theories to the lived religion perspective, social sciences have proposed analytical frameworks to understand the ways in which people relate to religious organizations, encountering once and again configurations which defy simplistic interpretations.

Secularization theories, which started to flourish in the 1960s, provided an explanation for religion's progressive disappearance as a driver of public life in the modern world (Martin 1978). From this perspective, the development of modernity would reduce the presence of religious institutions in nations' public life, as well as the extent of individuals' beliefs, which would at most be confined to their inner being. Later, the concept of secularization was revisited by analysts of religion in contemporary times, who still recognize it as a paramount concept to think about modernity, but question, most of all, its alleged universality, its imprecision (Hervieu-Léger 2015), and its limited usefulness for empirical analyses (Casanova 1994).

The centrality of institutions was a distinctive feature of the approach taken by the sociology of religions during much of their development. Since the 1990s, the autonomization of the faithful began to gain prominence. Although they would still be affiliated to some religious tradition, they chose to be "believers in their own way" (Parker 2008), "Catholics without Church," thus affirming their autonomy to relate to the sacred in their own terms (Mallimaci 2015). Debates about the reach of popular religiosity (Semán 2006; Ameigeiras 2008; Martín 2009; de la Torre 2012) brought into focus the interconnections among beliefs, miracles, and demons in everyday life (Mariz 1997; Birman 1997). The lived religion perspective revisits the relation between individuals and institutions, highlighting the centrality of the household - the domus - in the transmission of religiosity (Orsi 2002), centering on those religious practices, experiences, and expressions which involve bodies and materiality (McGuire 2008) and on narratives, in order to understand people's religious and spiritual worlds (Ammerman 2014). The lived religion perspective stresses the quests undertaken personally or with others and focuses on individuals as creators of religious practices and as not very interested in showing external marks of coherence (Morello and Rabbia 2019).

Thanks to the contribution of historical disciplines, research about individuals' religiosity shifts away from postulates according to which mediated and detached relations with institutions are to be found only in the present, whereas full identification with them belongs to the past. In Latin America, but especially in the South Cone region, the spread of Catholicism took place at a later time than in other geographies, and clergymen were too few to manage a large and scattered population (Barral 2007; Di Stefano 2007). The concepts of deinstitutionalization and dechristianization, which are used to describe the relation with the religious in Latin America, involve on the one hand the assumption that at some point the Catholic institution was in full control of the faithful while, on the other, also reduce the institution to its more rigid and bureaucratic aspects, dismissing institutions as sources of rituals, symbology, and relationships that subjects rely on and combine in original ways. Algranti et al. (2019): 53) propose to "understand instituting action as a dynamic, ongoing, changing project which to a certain extent contributes to producing the sacred in contemporary societies." Observing the margins and interstices (de la Torre 2012), as well as interactions and mediations, will let us understand what people do with their religion. 
The studies on Catholicism in pandemic times have addressed, from different angles, the relations between the institution and religious practices in the context of confinement and restrictions on mobility. For the Brazilian case, Py (2020) analyzed how politicians and the media utilized Christian discourse to readjust the conservative and fundamentalist constituency by resorting to messianic discourses about the salvation of the country and the economy as opposed to the social chaos of the quarantine. The mobilization of the Christian discourse as expressed in pandemic times, supported by the charismatic figure of president Bolsonaro, who contracted the disease and survived, upholds the "necropolitical stance." In this context, the Catholic Church shows conflicting internal trends: whereas the Catholic leadership (the CNBB or Episcopal Conference of Brazil) acknowledged the social impact of the pandemic and called upon the population to take special care, other currents aligned with the Charismatic Renewal and more conservative groups did not make any statement about the pandemic and started early on to demand the possibility of in-person attendance at masses and religious celebrations (da Silveira 2020).

The 2020 pandemic provided an unprecedented setting to reflect upon the relationship between people and institutions: forced to remain distanced from the faithful, churches reinforced, and found new ways to make themselves present. Confined at home and with no possibility to attend places of worship, the faithful reinvented their ties to beliefs and rituals. Pandemic times conjure up thoughts of disease, death, and fear; people in isolation experience loneliness and anxiety. These are problems that religions know how to address.

This article analyzes the everyday life religious practices of Catholic individuals during pandemic and lockdown times. We will focus on some topics which emerge strongly from field observations and which also allow us to reflect on the dynamics of religions between the individual resignifications and the innovative elaborations of religious traditions beyond institutional boundaries. First, we will concentrate on how religions address the pandemic situation and people's demands, which are mainly related to the need of emotional support and the management of emotions. Second, we will analyze the rituals and forms of community relations which result from online communication and which give rise to mixed, transnational, and innovative spaces.

\section{The Pandemic, the Lockdown, and Religion in Argentina}

On March 11th, 2020, the World Health Organization declared the COVID-19 outbreak as a pandemic. In Argentina, the first case was known in early March, and lockdown measures were introduced on March 20th. Religious institutions in Argentina embraced the government's provisions from the beginning and made their social aid structures available: they opened residential facilities for the hospitalization of mildly sick people and organized soup kitchens to support the unemployed in an economy with a high degree of informality. In April, the State Secretary for Cults stated: "Religion is fulfilling a helping role in these moments" . In addition to these measures, related to the historical relation between churches and state known as "subsidiary

\footnotetext{
${ }^{1}$ Interview with the Secretary for Worship (Ministry of Foreign Affairs and Worship), Guillermo Oliveri, April 4th, 2020
} 
laicism" (Esquivel 2016), the discourse of religious authorities supported the government measures. Unlike what happened in other Latin American countries, where the alliance between the government and some religious groups reinforced negationist theories about the virus and the pandemic (Oro and Alves 2020; Bandeira and Carranza 2020), places of worship in Argentina remained closed for months. "We are still not authorized to open the temple," said a handwritten sign on the door of a church in downtown Buenos Aires, while another sign in front of the image of the Virgin Mary read: "Do not touch. Health recommendation to prevent coronavirus infection", Religious authorities held online religious services, even during major Catholic festivities, which are celebrated with mass mobilizations of the faithful, such as Easter in April and the Youth Pilgrimage Walk to Luján in October. Bishops and priests sought new forms to communicate with the faithful: they recorded homilies targeted at different social sectors, celebrated masses through diverse platforms, organized webcasts from meaningful places, developed religious content for different social networks, and organized spiritual retreats that believers could follow through their cell phones. This section will delve into the circulation of these contents and the problems that they address. Virtual exchanges problematize two central topics: the body and emotions, on the one hand, and the family and home, on the other.

\section{Emotional Support, the Management of Emotions, and the Body}

When the lockdown was declared, the most visible and immediate consequence (like in all the countries where it was implemented) was a dramatic reduction of movement (del Cueto and Viotti 2020). For some time, people's everyday reality was confined to the limits of their home. Apart from those activities defined as "essential"-mainly those related to healthcare and the supply of food-relations with the "outside" developed through social media and virtual connections. Face-to-face interactions took place mostly with other people living in the same house, if any. The sudden and radical impoverishment of personal exchanges added to the reduction of physical mobility: people did not walk, moved around very little, and stayed within enclosed, often small, and overcrowded spaces. Religious practices were also fully affected by these spatial dynamics, and religious institutions quickly took this situation into account.

Among the main concerns of Catholic environments during pandemic times, regardless of their different theological and ideological positions, were the consequences of the lockdown context on people's mental health and the quality of their relationships. Religious specialists highlighted the issues of sedentary bodies, the possibility of domestic violence, and the anxiety caused by inactivity and confinement as some of the problems which motivated requests for help by the faithful. "Due to the pandemic, people ask for help, you need greater sensitivity to listen to them more; they are going through hard times, they feel the lockdown, they get depressed. They get down because they live in confinement," 3 stated a priest who is aligned with the Option for the Poor. "I have seen and I receive requests for help from people who are distressed and desperate due to problems to support their families, couple-related issues and

\footnotetext{
${ }^{2}$ Ethnographic observation, Buenos Aires, May 22nd, 2020

${ }^{3}$ Interview with Father J., priest of a parish in the north periphery of Buenos Aires, May 6, 2020
} 
loneliness"4, said a Charismatic religious leader. The growing demands placed on religious specialists - among others, those dedicated to health and well-being - gave rise to diverse strategies to meet people's needs. Remote support efforts were redoubled: priests and religious women made their cell phones and social media available to anyone who might ask for help, and networks were set up to support those in need of food, affection, or someone who would listen to them.

This line of action was also followed in rituals, which from the beginning of the lockdown made explicit reference to the pandemic. This made it possible to process conflicts, endure sorrow, and cope with bereavement. During virtual masses, praying for people ill with COVID-19 and healthcare agents was a must at the moment of the petitions and the presentation of the gifts. Prayers asked for the end of the pandemic and were also said for those who healed, fed, and looked after the sick and for the scientists who were working on the vaccines. During the Pentecost mass, Father P. prayed for "our beloved country, for its workers, for everyone suffering from hunger and distress, for healthcare workers, for those who help the poor and disadvantaged, so that everyone understands that we must take care of ourselves to take care of others, and so that a cure may be found as soon as possible for this virus that's killing us" Religious celebrations echoed and provided a sounding board for the care policies promoted by the State: personal care translated into collective well-being. In line with the theological positions of the Option for the Poor, it was repeated at celebrations that "we want to create a world where no man or woman will save themselves alone"6.

As months went by, deaths caused by COVID-19 became increasingly present in the day-to-day lives of the faithful. Remembering deceased loved ones is one of the most frequent practices among Catholics in Argentina. Over half of them talk to the dead in their everyday life (Giménez Béliveau and Fernández 2020). Celebrations, assuming one of the roles attributed to religion by Geertz (1973), started to comfort mourners and tried to give meaning to bereavement. In masses, a prayer is said for "our brothers who passed away, especially those who died from COVID-19"7. The names of the deceased are pronounced, and they are remembered for their commitment and work: the life and sacrifices of nurses, doctors, and caregivers are celebrated. The role of giving people the chance to put their mourning into words and remember their dead was important at a time when funeral rituals were severely affected by restrictions on mobility: the faithful honored the memory of the dead from home, and the religious institution proposed virtual spaces so that people would be able to say their last goodbye.

Based on a diagnosis of the importance of emotional support and integral health, some groups implemented mechanisms intended to preserve emotional and spiritual well-being. Although the management of emotions, especially those of women, has been a constant concern during the twentieth-century Catholicism and even before (Ospina Martínez 2004; Jusseaume 2014), a double convergence has been taking place for some years in certain Catholic environments and health organizations: on the one hand, the World Health Organization (WHO) has started to consider spirituality as part of the definition of health (Giumbelli and Toniol 2017), and, on the other, certain

\footnotetext{
${ }^{4}$ Interview with Father N., priest of a parish in the west periphery of Buenos Aires, October 8, 2020

${ }^{5}$ Pentecost mass broadcasted by Zoom and Facebook, May 31, 2020. Blessed Angelelli and Companions in Martyrdom chapel

${ }^{6}$ Same as previous note

${ }^{7}$ Father L.'s healing mass, broadcasted by YouTube on May 17, 2020
} 
Catholic spaces have approached self-help, developing mindfulness techniques. This process was the basis for the deployment of online techniques during pandemic times.

In March, several activities started to be developed by the Ministry of Awakening, led by Father L. Strategies with different formats, targeted at publics who were both close to and distant from the community, were put into practice. On Sunday afternoons, healing masses were live-streamed through YouTube, whereas on Tuesday afternoons, events would be streamed live through Instagram. Spiritual retreats were held over Zoom platforms, as well as 21-day retreats, transmitted through WhatsApp and intended to create prayer and spiritual growth habits. Activities were meant to weave ritual and formative practices which took into account the context of the pandemic, addressed people's problematic situations, and proposed solutions which involved working on oneself to control negative emotions and the difficulties caused by isolation.

Facing the present implied not only coping with bereavement over the death of relatives and acquaintances but also recognizing and bringing into greater focus pandemic fears of loneliness and disease. In the Easter prayer, Father L. said: "Lord, set me free from all fears; I fear the passing of time, coronavirus, loneliness, abandonment, having no one to support me and look after me"8. It is interesting to note that Charismatic movements in Argentina echo social concerns about the pandemic, naming it and processing it by praying, supporting the faithful, and putting at their disposal different online means so that they can be listened to and participate. This stands in contrast with what happens in other contexts. In Brazil, for example, the health crisis caused by COVID-19 is hardly mentioned by the Catholic Charismatic Renewal, even though this runs into open conflict with the communication policy of the Episcopal Conference of Brazil (CNBB) (da Silveira 2020). The social and political context, as well as the alignments of church movements, determines the possibilities of managing the pandemic in Catholicism.

Acknowledging feelings and emotional states is considered as the first step to act upon them. During the masses, which are more open ritual spaces, fears were uttered explicitly, they were given names, and people were invited to spiritual workshops and retreats to deal with them. The goal was to "provide support during isolation" through the "invitation to work upon ourselves". Workshops were held in weekly editions of two to four sessions, during which discussions centered on "letting go of the past," becoming free of "emotional dependency," "developing emotional and spiritual strength in times of crisis," and "enhancing self-esteem" ". The "healing process" was a key component of everyday practices: knowing oneself and finding one's mission in life go hand in hand with forgiving childhood wounds and getting rid of "thoughts of death, fear or sadness."

However, emotional health cannot develop without physical health: addressing emotions also implies taking care of the body. The body becomes the object of renewed concerns: seminars encouraged healthy habits, such as walking, exercising, dancing, and praying in motion. There was a return to the Catholic theology that proposes to

\footnotetext{
${ }^{8}$ Easter prayer, Father L., streamed through YouTube and Instagram channels on April 12, 2020

${ }^{9}$ Father L., first Instagram livestream, March 26, 2020

${ }^{10}$ These are verbatim quotes of the names of the workshop sessions led by Father L. by Instagram on Tuesdays.
} 
become aware of one's body, since we will "resurrect with this glorious, recognizable body for all of eternity"11. New value was placed on the body, as opposed to an "overly spiritual" spirituality. Sexuality, given new importance as part of the divine plan, and with a strongly heterosexual gendered perspective (male/female), was stressed in virtual seminars and retreats.

Working upon oneself and adopting a new, technology-mediated way of managing one's body and emotions have been the core themes structuring religiosity during the pandemic. The need to regulate and channel negative impulses became a major concern for religious groups. The next section analyzes the renewed importance gained by the home's intimate spaces which were newly sacralized as they became the center of everyday religious practices.

\section{The Household, the Family, and the Home Altar}

In Latin America, the interior of a house is often, also, a place of worship or, more precisely, includes a place destined to worship. Home altars, associated with the Catholic matrix, evidence at once the permanence of family and community traditions and how the faithful practice religion autonomously in their everyday life (Zuñiga and de la Torre 2020). Their arrangement can usually be changed, and they are able to contain a variable number of images and sacred objects. They also change over time: the same family can add or remove holy cards or images of the Virgin or their favorite saints. Home altars give rise to a number of diverse, plural, and autonomous practices. Saints are asked for protection and favors; people talk to them and perform specific micro-rituals to please them (Parker 1993). De la Torre claims that "they generally have human faces, are frequently experienced and treated as animate beings, and are believed to have their own will, specific tastes, sensory and communicative capabilities and extraordinary abilities to intervene in the life of the faithful" (de la Torre and Salas 2020:210).

Home altars express Catholics' attachment to material objects that support their relation with the world of symbols. Actually, $80.9 \%$ of Catholics in Argentina has holy cards, candles, or religious calendars (Giménez Béliveau and Fernández 2020). Home altars are not recent, and this practice is passed on from one generation to the next. One of the attendees to Father P.'s masses remembers the altar of an aunt of hers in the Argentine province of Mendoza: "In a corner of the kitchen, on a window sill, there was an image of a saint. From time to time, a candle was lit in front of him. Sometimes, the saint would be seen upside-down, as a punishment for not keeping his promises" ${ }^{\text {" }}$. Dialogs with saints are held on an everyday basis, generally in silence, and sometimes aloud: communication with them is partly public and with the participation of the family. The moments when they are worshipped depend on a combination of the liturgical calendar and believers' needs.

Autonomy from the institution is a characteristic of Latin American religiosity which has been highlighted in different contexts: recent data show that $65.4 \%$ of Catholics in Argentina choose to relate to God on their own (Mallimaci et al. 2020). Studies

\footnotetext{
${ }^{11}$ Father L., "Body, sexuality and love," conversation with Rebeca Barba, consecrated laywoman from the Regnum Christi Movement, live-streamed through Instagram on October 20, 2020

12 Interview with V., attendee to Father P.'s masses, on November 20, 2020
} 
about religiosity in pandemic times seem to confirm the trend towards the autonomization of believers: Meza (2020) has recently claimed that rituals in relation with the institution have lost intensity, while personal rituals tend to remain at prepandemic levels.

Home altars originate in the double tradition of domestic piety and believers' autonomy, and generate religiosities in the margins of institutions, which give rise to the circulation of objects, practices, and knowledge (De la Torre 2012) and let people demonstrate great inventiveness in the creation of rituals. Blessed objects which become part of altars, images bought at churches' religious items stores, and holy cards that commemorate special celebrations are signs of a two-way relationship with the institution, which provides consecrated elements that, in turn, sacralize domestic spaces. These items also generate exchanges among the faithful, as some objects cannot be bought but must be given as presents. Cristina, whom I visited in 2015, showed me her altar, where she had placed "the Virgin Mary of Luján, the Virgin of the Rosary, which has holy water. They gave me Saint Benedict as a present. You always have to have Saint Benedict at home [because] it drives away any evil anybody tries to do to you...." Then she showed me a water can and explained to me how she used it: "I always have holy water. I always put it in a sprayer and spray the children's beds when they go to sleep" $"$.

Pandemic and confinement times placed more demands on sacralized domestic spaces. Just like the home office that turned the home into a workplace, during virtual masses "the home becomes the religious setting" (Flores 2020:52). Attending virtual celebrations involved a specific preparation of the places from which the faithful participated: they learnt to choose the camera frame and what to show; the space was prepared and decorated, and images were selected and organized according to clear identity criteria. Like with the old home altars, the new spaces prepared for religious celebrations during the lockdown showed variety and fluidity: in addition to flowers and candles, they would display images of saints and virgins recognized by the Church next to images of popular saints, community leaders, and political leaders sacralized by some sectors like Eva Perón and Néstor Kirchner.

During the masses celebrated at the Blessed Angelelli and Companions in Martyrdom chapel, the community, clearly aligned with the Option for the Poor, expressed its theological-pastoral position through the iconography selected. The faithful would celebrate mass with pictures of Father Mugica, a priest who was assassinated by paramilitary groups in Argentina in 1975, images of Oscar Romero, a Salvadorian bishop killed by his country's government in 1980, or Enrique Angelelli and his companions in martyrdom of faith, murdered by the Argentine military dictatorship in 1976. The iconographic choices of the Ministry of Awakening also express its clearly revivalist ideological-pastoral position: the virgins of San Nicolás and Luján, and medals bearing the effigy of Saint Benedict, recognized for his action against the devil, are profusely worshipped in Charismatic movements.

Altars create "connections among paraecclesial practices, the institutional, and family or individual devotional practices" (de la Torre and Salas 2020:214). Worshippers take resources and knowledge provided by the Catholic Church and combine them

\footnotetext{
${ }^{13}$ Interview with Cristina, parishioner of Father C.'s parish, San Fernando, province of Buenos Aires, November 2, 2015.
} 
creatively with elements from other traditions, demonstrating a rich religious imagination which is reflected in family and home spaces. During the lockdown, the family acquired a strong meaning in domestic spaces, which for many people are also family spaces: day-to-day life in pandemic times was populated by the family. Concerns about elderly and distant relatives, the situation of having to live in close proximity to family members who shared the same household or the evidence of loneliness resulting from conflictive or estranged families became everyday topics, also brought to the fore by religious institutions and their agents.

The presence of religion at home reinforced the association between the family and the transmission of beliefs, underscored in both empirical studies (Giménez Béliveau and Mosqueira 2011; Zaros 2018a, 2018b; Zuñiga and de la Torre 2020) and in the sociological tradition which stresses the association among the family experience, the emergence of subjects' personality, and religious belonging (Dias Duarte 2006). Revivalist and Charismatic movements, in particular, implemented a number of strategies intended to prompt reflection upon family relationships and encourage efforts to harmonize them and to convert non-practicing family members: comforting and listening to others in difficult times are activities that often coincide with evangelizing campaigns and attempts to grow the numbers of group members. Women are one of the targets of preaching and are at the center of activities. This is not only because most followers of celebrations and seminars - as used to be the case before the pandemic, on the other hand-are women but also due to the association among femininity, emotions, and balance in domestic spaces. "A woman's essence is love, because emotional intelligence is important in women, since we women are constant emotion... In this process, you have to manage your emotions," claim Father L. and her guest in a conversation held at a workshop about the body, sexuality, and love $\mathrm{e}^{14}$.

Concerns about the health of family members and the need to manage cases of conflict-ridden cohabitation were key topics of the healing masses celebrated by the Ministry of Awakening, in response to its followers' demands. Prayers for the familyas well as for health - came first among believers' petitions in the virtual masses celebrated by Father L. each Sunday during 2020. Parents, children, grandchildren, and spouses were mentioned in prayers, which were said for them, for their health, and for their integration into Christian life: "I pray for my daughters and my husband, so that he may come closer to you, Lord Jesus," "so that our family can be as united as it always was," "please deliver my sister from any resentment against my dad, heal her, cure her, set my family free from ties," 15 the faithful would ask.

The family, health, old unresolved conflicts, and those arising from increased cohabitation: people's everyday life was fully impacted by the pandemic and the lockdown, and religion also made its appearance in confined spaces. In this unprecedented context, the interior of the home became at once a metaphor and a concrete experience of an intimist, practiced, autonomous religiosity, which negotiates knowledge and resources with the institution.

\footnotetext{
${ }^{14}$ Father L., "Body, sexuality and love," conversation with Rebeca Barba, consecrated laywoman from the Regnum Christi Movement, live-streamed through Instagram on October 20, 2020

${ }^{15}$ Comments from believers about Father L.'s healing mass, streamed on November 29, 2020
} 


\section{The Sacred and the Community on the Screen}

During the 2020 pandemic, religions considered the need to move rituals, activities, and celebrations to the virtual realm. This process took place in different ways depending on traditions, the relationship with the materiality of practices, and geographical areas (Flores 2020). However, before circumstances forced this leap into the virtual world, diverse religious and spiritual experiences had developed projects that involved social media and virtual spaces in different proportions and which were the focus of academic reflection. The use of digital technologies by religious groups (El-Tahawy 2008; Corvalan Espina 2019), cyberspace as a field of conflict (Bloch 2017), and the transformations and new horizons generated by these uses (Vitullo 2016; Cloete 2016) attracted attention in a context of transformation of technology-mediated social bonds.

Studies of digital religion originated in the observation of the communicative uses of technology from a functionalist framework and then shifted to a more culturalist perspective which stresses the - even historical - interweaving of technology with the transformations of religions (Horsfield 2015; Cloete 2016). Campbell and Vitullo first identify three waves (Campbell 2011) and then four stages (Campbell and Vitullo 2016) in studies of online religion: the first one is monographic and consists of describing communities; the second one stresses communities' common characteristics and categorizes them; the third one focuses on their use of digital media; and the fourth one centers on the online and offline interfaces of discourses and practices.

During pandemic and lockdown times, social media pervaded people's everyday life more intensively and took up more of their time than they used to; they became embedded in their day-to-day life, stressing the link between the online and offline domains. Thus, research faces new challenges, further reinforcing the intuitions held by Lövheim and Campbell (2017), who claim that "as digital technology continues to saturate personal as well as public, leisure as well as political, modes of communication and being in the contemporary world, researchers investigating digital religion are starting to engage with the existential, ethical, and political implications of these intersections, which calls for the application of new theoretical and methodological tools."

The study of Catholicism during the period considered shows that the integration of the online and offline worlds involved fewer tensions and conflicts than in other religious traditions for which copresence and interaction with the sacred space are essential for performing rituals (Flores 2020). The Catholic Church has a long experience of adapting to new circumstances, and the 2020 pandemic was no exception. The next section will examine some of the modalities of Catholicism's everyday practices in Argentina.

\section{Catholics and Social Media During Confinement}

When the lockdown was declared in Argentina on March 20th, 2020, the main concern of Catholic leaders, from the Episcopal Conference of Argentina to parish priests, was caring for their communities and finding virtual resources that would enable the continuity of celebrations. The faithful, at the same time, expressed their need to remain in touch with worship practices by demanding actions from authorities and religious 
leaders and generating their own rituals and meetings. The institution reinvented itself with the use of virtual media, which was based on initiatives from its leaders and, most of all, driven by entrepreneurs, people who made their ingenuity and knowledge available for their own growth, that of their group and of Catholicism in general.

The Argentine Church held virtual events on significant liturgical calendar dates: the Easter celebration in April and the Pilgrimage Walk to Luján in October. In line with Vatican directives, the Passion of Christ, the Stations of the Cross, the Easter Vigil, and the Easter Sunday mass were broadcast by television. Easter celebrations were presided over by Cardinal Mario Poli, Archbishop of Buenos Aires and Primate of Argentina. Some months later, in October, on the date of the traditional pilgrimage walk to Luján, which gathers thousands of young people every year (Fogelman et al. 2013), the Church made the same decision: the pilgrimage would take place virtually. In the pilgrimage website, the faithful could leave their intentions and petitions for the Virgin. The site also streamed songs and interviews with pilgrims who were at home, as well as the central mass, presided over by Cardinal Poli and other bishops ${ }^{16}$. In addition to the transmissions from the basilica organized by the Episcopal Conference of Argentina's Archdiocesan Commission for Popular Piety, content was also streamed by countless parishes and communities which, repeating the structure of the celebrations, every year organize their members to participate in the walk.

In the same way as the pilgrimage to Luján gave visibility to a myriad of transmissions, Catholic initiatives multiplied, and parish communities or ministries developed specific forms of virtual communication. This migration to the virtual realm, forced by circumstances, was marked by fragmentation: each group sought a way to reach its own members, and the faithful sought ways to meet with each other. The key characteristic of these initiatives, rather than the use of centralized platforms, was their reliance on social networks: since they were within closer reach and the faithful and parish teams knew how they worked, social media made themselves present in believers' everyday life with unprecedented intensity, filling in the spaces, now left vacant, of meetings with friends and family. Religion, too, traveled across these media.

The flourishing and consolidation of this multiplicity of digital undertakings are one of the most interesting phenomena in the field of Catholicism during pandemic times. As a result of individual or group experiences, Catholic digital entrepreneurs took forms of communication from other social domains and used them to develop innovative projects aimed at connecting believers among each other and evangelizing. "Social media have come to me, and digital evangelization is part of my life," claims Margarita, invited by Father L., during an event streamed through Instagram in August 2020. It should be noted that religious entrepreneurs are not a new phenomenon: there is research about Catholic specialists who have developed projects in the economic domain (Seabright 2016) and particularly in the fields of politics and social activism (Catoggio 2016). The unprecedented circumstances of the 2020 pandemic consolidated a type of religious entrepreneur whose distinctive features were their inventiveness in using social media and communication and the creation of virtual spaces with diverse communication functionalities.

The heterogeneous communication modalities used in Internet have been listed by Jungblut (2004), who has also highlighted how they enable different kinds of

$\overline{16}$ The webcast could be followed at http://peregrinacionlujan.org.ar/. 
participation. Along these lines, the study of Catholics' activities during pandemic times shows different modalities of social media use. The Catholic Church has several official web pages, such as those of the Episcopal Conference of Argentina, the Basilica of Luján, and the Pilgrimage Walk to Luján. The first one is used to provide information and announce activities, whereas the other two are used to stream celebrations through YouTube. This platform is used by the Church and religious entrepreneurs for streaming content in the style of television broadcasts. It enables communication with massive audiences, who can view content live or on demand, and also shows the success of the events as measured by the number of followers. The use of YouTube is an attempt to establish a one-way relationship with viewers, which the channel owner can regulate by turning on comments or not. It resembles more traditional broadcasts, and most of the streamed content consists of liturgical celebrations, such as masses, homilies, and the prayers of the rosary. Some communities use the Facebook live streaming function in the same way, so that the video will remain in the web and be available for viewing later.

A similar function, but adapted to a younger public, can be found on Instagram, which is used by religious entrepreneurs to stream other type of content: workshops, seminars, or series with fixed schedules. Transmissions are more relaxed, and it is not usual to post-liturgical celebrations. Many men and women entrepreneurs associate their Instagram posts to TikTok, a network that shares with Instagram the same type of public and is characterized by the use of song fragments with video. Since the pandemic began, a group of priests and nuns started to post short videos in this social network, combining music, dancing, and humor. In July 2020, a group called Catholitokers was created. This group is comprised of friars, nuns, and priests under the age of 40 from different Latin American countries (Mexico, Colombia, and Argentina, among others). They are characterized by a common aesthetic, visible in the attire they wear and the objects they use, as well as in their gestures and dancing: videos feature the habit, the Bible, and a dove. User names make reference to their double condition as religious men or women and social media users: @ sorSelfie (selfie nun), @ FrayFoto (picture friar), El arquero de Dios (God's goalkeeper), and Curas Locos (crazy priests). This type of content is designed for fast consumption. In this way, faith seeps through the interstices of social networks and is consumed on an everyday basis. In December, Friar Santiago OFM, a Franciscan friar who defines himself in his Instagram profile as happy, creative, and spiritual, posted a video on TikTok moving his arms to reggaeton music and issued a challenge to his followers: "Take your Bible, open it in the Book of Proverbs, find the chapter with the same number as the month of your birthday, now find the verse with the same number as the day of your birthday. What can you share with us about the word of God? Wow!".

Messaging apps are widely used by religious entrepreneurs: getting a WhatsApp or Telegram message makes it possible to personalize exchanges. Actually, these networks are used, among other things, for personal communications with priests or religious women and for exchanges among group members to organize activities. However, exchanges of a different type also emerged: the Ministry of Awakening used this network to organize 21-day spiritual retreats (Healing and Personal Transformation Retreat). People could participate by enrolling in advance, with a limited number of spots available, and on each day, they would receive a prayer, a passage of the Bible and a Roadmap for their everyday activities. Father L. would explain the dynamics of 
the retreat through other social networks (Instagram) and promote it in the masses streamed by YouTube. The use of messaging apps makes it possible to send personalized Catholic content and ensures presence through a cell phone every day. It is also a means to an end: its goal is to create the habit of meditation and prayer, since it is believed that an action must be repeated for 21 days to become a habit.

Facebook and Twitter were more marginally used: they promoted virtual activities, retransmitted content produced for other social media, and communicated opinions of the more politically active groups about current topics.

For some groups, virtual meeting platforms became a fundamental tool to stream religious celebrations. Zoom, Jitsi, Cisco, and Teams operated as meeting places in those celebrations which were more open to worshippers' participation. These platforms made it possible to partially recreate in-person meetings on the screen, given that, unlike the practically one-way transmissions through Instagram or YouTube-which only allow users to leave comments - they give participants the possibility to hold exchanges. Virtual masses are celebrated on these platforms, alternating the reading of biblical passages with petitions from the faithful, and some time are also allocated for believers to engage in conversation at the end of celebrations.

Through the combined use of several social media, the Church, which is heterogeneous and plural, reinvented itself also through its entrepreneurs and driven by the demands of the faithful. People were fully impacted by these trends and were confronted with innovative proposals which percolated into the increased predominance of social networks during times of confinement. The next section will show the distinctions between two Catholic communities and how they develop theologically and ideologically contrasting projects through a differentiated use of online communication.

\section{The Community Through the Screen}

The combination of different digital media and activities depends on communities' connection, growth, and evangelization projects. During the pandemic, the groups analyzed pursued different goals: the Ministry of Awakening, with a revivalist orientation, interpreted the pandemic and confinement as having a twofold meaning: at the individual level, it would let people work upon themselves, and the lockdown context would promote such work, which was aided by the retreats, seminars, and celebrations that the group uploaded to social media. At the community level, it would further group growth; this was even supported by visions of its founder, who during late 2019, based on prophetic interpretations of the Gospels, had seen a moment when great numbers of fish would be hauled for the community. Sunday masses, streamed through YouTube, started to have massive attendance and came to gather as many as 2000 worshippers. Every Sunday, Father L. would urge attendees to grow even more: he invited them to the retreats and seminars, mentioned the channels to help online, and encouraged them to evangelize and invite a friend to reach a larger public and more followers.

The Blessed Angelelli and Companions in Martyrdom chapel, aligned with the Option for the Poor and located in a low-income neighborhood in the periphery of the city of Buenos Aires, targeted its actions mainly at providing social aid to an impoverished population. The community focused on reinforcing soup kitchens in the face of the food emergency, and organizing a shelter home that provided medical and 
dental care, as well as a place to stay for addicts in recovery. Social media were used to promote solidarity projects (Facebook and Twitter) and to connect community members (WhatsApp). The need for community gatherings also emerged: since late April, masses started to be celebrated on Sundays through meeting platforms (Jitsi, Zoom). These masses became a meeting place without borders: streamed from the Eva Perón neighborhood, they were attended by people who connected from different places of Argentina, as well as by the priest's and believers' relatives in Spain. Masses continued to be held during all of 2020, even when restrictions on movement became more flexible and allowed some of the faithful to attend in-person celebrations. Celebrations on Sundays gathered about 50 attendees and were retransmitted through Facebook. Like in the case of in-person celebrations, Bible readings were distributed among community members, according to a sequence that had been circulated during the previous week.

The use of social networks is related to the type of undertaking. Virtual growth projects create a more stable structure: YouTube channels, institutional users with the same name in Instagram, Facebook, TikTok, and Twitter, planned content and means for fundraising. In contrast, projects that focus primarily on gathering the community during pandemic times and which are thought of as a substitute for face-to-face meetings and a transition until the latter can be held again organize temporary, more flexible networks, with less homogeneous denominations and content. Paraphrasing Marshall McLuhan, the online medium is also the message, and the choice and use of networks are modeled on the existing community project.

The distinctive features of communities' identities and their stance within Catholicism were also evidenced in discussions about whether certain rites could be streamed online. The Eucharist requires for people to be present, given the consecrated character of the object. The host can only be consecrated by a priest, who in turn should also distribute it in particular conditions, i.e., if the faithful have confessed. Within Catholic symbolism, the consecrated host is considered as the real presence of the body of Christ, which is offered to men and creates community, and cannot be touched outside sacred times and spaces. For the faithful in times of lockdown, it brings comfort and sanctifies the body and the life of those who receive it. The Church's official position followed the established canons, which propose "spiritual communion," a prayer that affirms the belief in the sacred character of the host and says that "since I cannot now receive you sacramentally, come spiritually into my heart." This prayer, which is transmitted in a recorded message, ends by saying: "I embrace You as if you were already there and I unite myself wholly to You"17. This is the option chosen by the Ministry of Awakening, which live-streams the consecration of the host by the priest while the faithful, at home, practices spiritual communion. In contrast, the priests aligned with the Option for the Poor proposed "that people should bless the bread and the wine, they should feel encouraged to consecrate them, in an exceptional situation like the one we are going through" ${ }^{\text {. }}$. Communities call this celebration the "breaking of the Bread" and consider it to be as sacred as a mass, but without discussing ecclesiastical rules.

\footnotetext{
${ }^{17}$ One of the variants of Saint Alphonsus Liguori's prayer is available at the Vatican webpage, https://www. vaticannews.va/es/oraciones/comunion-espiritual.html.

${ }^{18}$ Interview with Father J., priest of the Option for the Poor, May 6, 2020
} 
However, in addition to the sacrament of the Eucharist, which as already mentioned can be celebrated in different acceptable ways, other elements are used too in rituals. These objects, called sacramentals, have a lower degree of sacredness, and their properties can be transmitted through the screen. The July masses of the Ministry of Awakening announced "a time of restoration for your life and your family"19, and water, salt, and the medal of Saint Benedict were blessed. These consecrated objects are used by the faithful to bless their homes: they spray the holy water where the consecrated salt has been dissolved and wear Saint Benedict's medal on their body or place it at the entrance of their house.

The year of the confinement allowed the emergence and consolidation of virtual communities of different characteristics but with some common features. On the one hand, the abundant online Catholic offer allowed individuals to come closer to each other. For these people, who were living in confinement and with reduced mobility, virtual celebrations were a source of reassurance, communion with others, support, and spiritual development. On the other, the illusion of distance and closeness that characterizes the use of networks made it possible to express individual and family demands through chats and comments in social media: petitions were made asking for health and for the deliverance of sons and daughters, parents, and spouses. In these virtual spaces, the predominantly female attendees found a place where to publicly voice feelings and emotions that were difficult to express. One last characteristic of virtual interactions is the consolidation of transnational communities. The online world enables exchanges across different geographies, and attendance of people from distant places is celebrated.

Virtual communities are rooted in ecclesiastic and political practices, ideas, and demands that were already present in pre-pandemic times; they consolidate projects which combine the online and offline domains and give continuity to their previous plans, emotional, spiritual health, and deliverance, in the Ministry of Awakening, and the political position aligned with the Option for the Poor, in the case of the Blessed Angelelli chapel. During confinement times, Catholic practices which the faithful were already familiar with became part of their everyday lives in new forms.

\section{Conclusions}

During the 2020 pandemic, social relationships were dramatically altered, being affected by the lockdown health policies. Religious practices, like work, school, and leisure, became confined to people's homes. The purpose of this article was to analyze the practices of Catholic worshippers in their everyday life during the pandemic, through a digital ethnography study conducted among Catholic groups during 2020. In particular, it intended to delve deeper into the interactions between the faithful and the institution in the light of the contributions of the lived religion literature.

Our primary intent was to survey institutional proposals and the demands expressed by the faithful. In difficult times, marked by disease and death, groups' most salient proposals were reassurance, comfort, and the possibility to process bereavement, as well as support for managing emotions. The home became the center of religious practices and returned to the Latin American tradition of home altars. The Catholic

\footnotetext{
${ }^{19}$ Flyer sent by WhatsApp announcing the mass of July 26, 2020, Ministry of Awakening
} 
institution developed initiatives to support domestic religiosity, providing rituals that could be feasibly performed in the pandemic context, as well as knowledge and sacralized objects that could be transmitted through the screens and facilitated sacred items for everyday life. Virtual interactions made their appearance in worshippers' dayto-day life and took place on the boundaries of institutions.

Catholic groups' leap into the virtual world took different forms: it evidenced the various projects supported by the groups, which were reflected by the distinct modalities of social media use. These projects, aimed at connecting communities separated by confinement and at expanding groups, followed communities' ideological, theological, and ecclesiastic policy lines: within Catholicism, some leaders saw in the leap to the virtual realm a chance to grow, while others were unable to recreate virtual communities. The use of social media strongly promoted transnational connections. Communities are spread across different countries and celebrate their wide-ranging presence, which they attribute to evangelization projects. The flexibility of the religious entrepreneurs who work within the Church, though with relative autonomy, enables the growth of communities in the margins and that of believers who move across different spaces as they go on their quests. Here, rather than a monolithic bloc, the Catholic institution appears to encompass a number of both integrated and disaggregated practices, set in motion by agents who operate at independent paces and with different intensity as they attempt to adapt to difficult times and unprecedented contexts, something that the Latin American Church has been doing since Catholicism disembarked on this land.

\section{References}

Algranti J, Mosqueira M, Setton D (2019) Pensar sin Iglesias: el hecho institucional como problema de estudio. In: Algranti J, Mosqueira M, Setton D (eds) La institución como proceso. Configuraciones de lo religioso en las sociedades contemporáneas, Biblos, Buenos Aires, pp 29-58

Ameigeiras A (2008) Religiosidad popular: creencias religiosas populares en la sociedad argentina. Universidad Nacional de General Sarmiento- Biblioteca Nacional, Buenos Aires

Ammerman NT (2014) Sacred stories, spiritual tribes: finding religion in everyday life. Oxford University Press, New York

Bandeira O, Carranza B (2020) Reactions to the Pandemic in Latin America and Brazil: are religions essential services? Int J Lat Am Relig 4:170-193. https://doi.org/10.1007/s41603-020-00116-0

Bárcenas Barajas K (2019) Etnografía digital: un método para analizar el fenómeno religioso en Internet. In: Suárez HJ, Bárcenas Barajas K, Delgado Molina C (eds) Estudiar el fenómeno religioso hoy: caminos metodológicos. Universidad Autónoma de México, México, pp 285-313

Barral ME (2007) De sotanas por la Pampa. Religión y sociedad en el Buenos Aires tardocolonial. Prometeo, Buenos Aires

Birman P (1997) Males e malefícios no discurso Neopentecostal. In: Bírman P, Novaes R, Crespo S (eds) O mal à brasileira. UERJ, Rio de Janeiro, pp 62-80

Bloch JP (2017) Cyber wars: Catholics for a free choice and the online abortion debateAuthor(s): Jon P. Bloch. Rev Relig Res 49(2):165-186

Campbell HA (2011). Internet and religion. In: Consalvo M, Ess C (eds) The Handbook of Internet Studies, https://doi.org/10.1002/9781444314861.ch11

Campbell HA, Vitullo A (2016) Assessing changes in the study of religious communities in digital religion studies. Church Commun Cult 1(1):73-89. https://doi.org/10.1080/23753234.2016.1181301

Casanova J (1994) Religiones públicas en el mundo moderno. PPC, Madrid 
Catoggio MS (2016) Los desaparecidos de la Iglesia. El clero contestatario frente a la dictadura, XXI edn. Siglo, Buenos Aires

Cloete AL (2016) Mediated religion: implications for religious authority. Verbum et Ecclesia 37(1):1-6. https://doi.org/10.4102/ve.v37i1.1544

Corvalan Espina JM (2019) Religión católica, nuevas tecnologías y redes sociales virtuales: ¿Configura populismo la comunicación del Papa Francisco en la era del Internet 2.0? deSignis 31. Populismo(s). Intersecciones en las Ciencias Sociales / Cuarta Época. Serie Intersecciones (julio-diciembre de 2019), 339-357

da Silveira ES (2020) “Catholicovid-19” or Quo Vadis Catholica Ecclesia: the Pandemic Seen in the Catholic Institutional Field. Int J Lat Am Relig 4:259-287. https://doi.org/10.1007/s41603-020-00114-2

de la Torre R (2012) La religiosidad popular como "entre-medio" entre la religión institucional y la espiritualidad individualizada. Civitas - Revista de Ciências Sociais 12(3):506-521

de la Torre R, Salas AV (2020) Altares vemos, significados no sabemos: Sustento material de la religiosidad vivida. Encartes 3(5):206-226

del Cueto C, Viotti N (2020) Ni solidarios, ni egoístas. Moralidades prácticas durante la pandemia. Prácticas de oficio 25, accesed http://revistas.ungs.edu.ar/index.php/po/article/view/35/29

Di Stefano R (2007) Política y religión: problemas conceptuales del estudio de sus vínculos durante la primera mitad del siglo XIX argentino. Sociedad y religión 28(29):127-135

Dias Duarte LF (2006) In: Dias Duarte LF, Heilborn ML, Lins de Barros M, Peixoto C (eds) Ethos privado e modernidade: o desafio das religiões entre indivíduo, familia e congregação. Família e religião. Contra Capa, Rio de Janeiro, pp 51-87

El-Tahawy A (2008) The Internet is the New Mosque. Fatwa at the Click of a Mouse. Arab Insight 1(3):11-20

Esquivel JC (2016) Religion and politics in Argentina. Religious Influence on Legislative Decisions on Sexual and Reproductive Rights. Lat Am Perspect 43(3):133-143. https://doi.org/10.1177/0094582X16629459

Flores FC (2020) Espacialidad y religiosidad en tiempos de covid-19: apuntes preliminares desde la geografia de las religiones. Espaço e Cultura 47(UERJ):37-54

Fogelman P, Ceva M, Touris C (eds) (2013) El culto mariano en Luján y San Nicolás. Religiosidad e historia regional. Biblos, Buenos Aires

Geertz C (1973) Religion as a cultural system. In: Geertz C (ed) The interpretation of cultures. Basic Books Inc, New York, pp 87-125

Giménez Béliveau V, Fernández NS (2020) Católicos y católicas: sus creencias, prácticas y opiniones en Argentina (2019). Sociedad y Religión 55:97-120

Giménez Béliveau V, Mosqueira M (2011) Lo familiar en las creencias y las creencias en lo familiar: Familia, transmisión y religión en la Argentina actual. Cult Relig 5(2):154-172

Giumbelli E, Toniol R (2017) What is spirituality for? New relations between religion, health and public spaces. In: Blanes R, Mapril J, Giumbelli E, Wilson E (eds) Secularisms in a Postsecular Age? Religiosities and Subjectivities in Comparative Perspective. Palgrave-Macmillan, Nueva York

Hervieu-Léger D (2015) Hay que luchar para trabajar, escribir y pensar en el propio idioma. Sociología de la religión en francés. Entrevista de Verónica Giménez Béliveau Sociedad y Religión 43:146-168

Hine C (2015) Ethnography for the Internet. Embedded, Embodied and Everyday. Bloomsbury, London

Horsfield P (2015) From Jesus to the Internet. A History on Christianity and Media. Wiley, West Sussex

Jungblut A (2004) A heterogenia do mundo on-line: algumas reflexões sobre virtualização, comunicação mediada por computador e ciberespaço. Horizontes antropologicos 10(21):97-121. https://doi.org/10. 1590/S0104-71832004000100005

Jusseaume A (2014) De la disgrâce à la grâce: La trajectoire des Filles de la Charité « de condition » au XIX ${ }^{\mathrm{e}}$ siècle. Hypothèses 17(1):255-266. https://doi.org/10.3917/hyp.131.0255

Lövheim M, Campbell HA (2017) Considering critical methods and theoretical lenses in digital religion studies. New Media Society 2017 19(1):5-14

Mallimaci F (2015) El mito de la Argentina laica. Capital Intelectual, Buenos Aires

Mallimaci F, Esquivel JC, Giménez Béliveau V (2020) Religiones y creencias en Argentina (2008-2019). Resultados de la Segunda Encuesta Nacional de Creencias y Actitudes Religiosas en Argentina. Sociedad y Religión 55

Mariz CL (1997) O demônio e os pentecostais no Brazil. In: Bírman P, Novaes R, Crespo S (eds) O mal à brasileira. UERJ, Rio de Janeiro, pp 45-58

Martin D (1978) A general theory of secularization. Harper, Nueva York

Martín E (2009) From popular religion to practices of sacralization: approaches for a conceptual discussion. Sociol Compass 56(2):273-285. https://doi.org/10.1177/0037768609103362

McGuire M (2008) Lived religion: faith and practice in everyday life. Oxford University Press, New York 
Meza D (2020) In a pandemic are we more religious? Traditional Practices of Catholics and the COVID-19 in Southwestern Colombia. Int J Lat Am Relig 4((2020)):218-234. https://doi.org/10.1007/s41603-02000108-0

Morello G, Rabbia H (2019) Cómo se vive la religión en Sudamérica. In: Rabbia H, Morello G, Da Costa N, Romero C (eds) La religión como experiencia cotidiana: creencias, prácticas y narrativas espirituales en Sudamérica. Fondo Editorial PUCP- Universidad Católica de Córdoba- Universidad Catolica del Uruguay, Montevideo, pp 9-27

Oro AP, Alves D (2020) Jair Bolsonaro, líderes evangÉlicos negacionistas e a politização da pandemia do novo coronavírus no Brasil. Sociedad y religión 54:121-147

Orsi R (2002) The Madonna of 115th Street. Yale University Press, Yale

Ospina Martínez MA (2004) Apuntes para el Estudio Antropológico de la Alabanza Carismática Católica. Convergencia, Revista de Ciencias Sociales 11(36):31-59

Parker C (1993) Otra lógica en América Latina. Religión popular y modernización capitalista. Fondo de Cultura Económica, Santiago

Parker C (2008) Mentalidad religiosa post-ilustrada: creencias y esoterismo en una sociedad en mutación cultural. En publicación: América Latina y el Caribe. In: Alonso A (ed) Territorios religiosos y desafíos para el diálogo. Consejo Latinoamericano de Ciencias Sociales, Buenos Aires, pp 337-364

Py F (2020) Bolsonaro's Brazilian Christofascism during the Easter period plagued by Covid-19. Int J Lat Am Relig 4(2020):318-334. https://doi.org/10.1007/s41603-020-00120-4

Seabright P (2016) Religion and entrepreneurship: a match made in heaven? Arch des Sci Sociales des Religions 175:201-219

Semán P (2006) Bajo continuo. Exploraciones descentradas sobre cultura popular y masiva. Editorial Gorla, Buenos Aires

Vitullo A (2016) New Age goes online: relocating spirituality in virtual spaces. The Study of Damanhur. Methaodos Revista de ciencias sociales 4(2):339-348

Zaros A (2018a) El perfume de los ramos de Lulav. La memoria religiosa familiar entre tradición y continuidad: el caso de una comunidad judía italiana. Religião Soc 38(3):155-172. https://doi.org/10. 1590/0100-85872018v38n3cap07

Zaros A (2018b) Los herederos de los abuelos: sobre la socialización religiosa en familias de diferentes credos en Buenos Aires. Debates do NER 19(33):235-262

Zuñiga C, de la Torre R (2020) Cambio religioso en Guadalajara. Perfiles y comportamientos a lo largo de tres décadas (1996-2016), Guadalajara. Universidad dee Guadalajara- El Colegio de Jalisco

Publisher's Note Springer Nature remains neutral with regard to jurisdictional claims in published maps and institutional affiliations. 